\title{
An Assessment of the Physico-Chemical Parameters of Ihuku River
}

\author{
Ifeoma J. Okereke \\ (Department of Environmental Resource Management)(Abia State University, Uturu, Nigeria)
}

\begin{abstract}
Levels of physico-chemical parameters ( $p H$, phosphate, hardness, biochemical oxygen demand, temperature, total solids, heavy metals, etc) were determined in the water samples collected from Ihuku River. The results of the physico-chemical analysis showed that the levels of Lead, Chromium, Nickel and Cadmium were higher than is fit for consumption. In general, water samples from Location 2 were found to be more contaminated than those from Location 1. The car wash and greater population use at Location 2 could be the reason. Some of the physico-chemical parameter values falls within the World Health Organisation and Nigeria Standard for Drinking Water Quality limits for drinking water, some are not. Therefore, source protection is proposed for these bodies of water if sustainable development is to be attained in the area. Keywords: heavy metals, Ihuku River, physico-chemical parameters, Uturu, water quality,
\end{abstract}

\section{Introduction}

Safe drinking water, sanitation and good hygiene are fundamental to health, survival, growth and development. Water of good drinking quality is of basic importance to human physiology and man's continued existence depends very much on its availability. An average man (of $53 \mathrm{~kg}-63 \mathrm{~kg}$ body weight), requires about 3 litres of water in liquid and food daily to keep healthy [1]

Ihuku so named by the ancestors of Uturu Clan is the popular major surface water that cuts across all the seven major villages that make up Uturu. It is one of the commonest resources that interconnect about twenty four autonomous communities which make up these seven villages. It has been the major source of water supply for domestic, agricultural, mini industrial and other uses for Uturu people from time immemorial. Over the years, a lot has changed within and around the Ihuku River without any attention given to it. As a result of population increase, the number of people seeking this resource increased, adding pressure on its quality and quantity.

Development has introduced additional foreign uses and effluent discharges. For instance, car wash businesses are now sited along this river, which serves as the source of water for this business activity and also a recipient of its laundry effluents. Block industries sited around Ihuku also makes use of this stream for their business activities. This is also a source of pollution.

On many occasions, tankers coming to supply fuel/diesel to the few filling stations in and beyond Uturu have fallen along the meandering Absu-Uturu main road, the effluents of such disasters - oil, grease, gas , ashes, find their way into the Ihuku which crossed the main road. It remains the major 'bathroom' for many especially school children and farmers. The quality of water is important for the well-being of the environment, society and the economy [2] but the geology of Uturu is such that attempts made to provide alternatives such as wells and borehole have proved abortive. This has restricted the poorest of the poor in this area to drinking this water and as well impeded development as no firm that requires 'good' water exists yet.

Because overall greater productivity is attained with a healthy people, an analysis on the physico-chemical parameters of Ihuku was carried out. The findings of the analysis will prove to be quite informative to the daily consumers of Ihuku, as it is of significant importance to the entire Uturu dwellers.

\section{Materials and Methods}

\subsection{The Study Area}

The study areas are located N05 49.540 E007 24.974 (Location 1) and N05 49.567 E007 26.062 (Location 2) These Ihuku that crossed the main roads are the central focus of this study. They receive effluents from drainages, runoffs, block industries, waste sites at Abia State University junction etc

\subsection{Materials}

All chemicals used were of Analytical grade except Sulphuric acid which was a general purpose reagent. Amber bottles with polypropylene cap were used for the collection of water from each sample site.

1.3. Methods

This study was carried out July $1^{\text {st }}-$ July $6^{\text {th }} 2013$. Water temperature and $\mathrm{pH}$ were measured on-site using mercury-in-glass thermometer and a pre-calibrated Hanna electronic pH meter (Hanna instruments, H18915ATE, Singapore) respectively. Samples were collected for laboratory analysis of other parameters. 
Total Dissolved Solids were determined gravimetrically [3]. Total Hardness was determined by titrating water samples with standard EDTA titrant with Eriochrome black-T as indicator according to standard methods[4]. Dissolved Oxygen was determined using the Modified Winkler-Azide Method [4], while Biochemical Oxygen Demand $\left(\mathrm{BOD}_{5}\right)$ was determined by the difference between DO of samples immediately after collection and DO of samples after incubation at $20^{\circ} \mathrm{C}$ for five days.Nitrate was determined using UV-Visible Spectrophotometer [5]. Heavy Metals were determined instrumentally using the Atomic Absorption Spectrophotometer (AAS). Phosphorus was determined following the Vanodomolybdophosphoric acid colorimetric method [6]. Sodium ion $\left(\mathrm{Na}^{+}\right)$and Potassium ion $\left(\mathrm{K}^{+}\right)$were determined by the flame photometric method. Calcium ion and magnesium ion were determined by Versenate EDTA complexemetric titration.

\section{Results And Discussion}

Table 1 show the physico-chemical parameters of Ihuku water from Location 1 and Location 2.

Temperature has significant impact on the growth and activities of ecological life and it greatly affects the solubility of oxygen in water. High water temperature enhances the growth of micro organisms and may increase problems related to taste, odour, colour and corrosion [7].The temperature of Ihuku was found to be in the range of $24.3^{\circ} \mathrm{C}-27.5^{\circ} \mathrm{C}$ in Location 1 and $27^{\circ} \mathrm{C}$ in Location 2 . The temperature in location 1 was found to be inconsistent unlike at Location 2. Destruction of plant cover in some parts in an attempt to build a filling station which failed could be the reason.

Hardness is caused by multivalent metallic cations; those most abundant in natural waters are Calcium and Magnesium [8]. Water with a total hardness in the range of 0 to $60 \mathrm{mg} / \mathrm{L}$ is termed soft, from 60 to 120 $\mathrm{mg} / \mathrm{L}$ moderately hard, from 120 to $180 \mathrm{mg} / \mathrm{L}$ hard, and above $180 \mathrm{mg} / \mathrm{L}$ very hard [9]. Based on this, the water samples from location 1 can be classified as soft water with a hardness range of $50-60 \mathrm{mg} / \mathrm{l}$ while Ihuku at location 2 can be termed hard owing to its hardness range of $60-70 \mathrm{mg} / \mathrm{l}$.

$\mathrm{pH}$ is the best indicator of the presence of acids and alkalis [10].pH was found in the range 6.0-6.4. These were slightly below the 6.5-8.5 set by NSDQW. Alkaline drinking water plays an important role in ridding the body of mercury and other toxins [11].The more acidic the body is, the more it holds onto (heavy) metals. Heavy metals in turn create a high oxidative stress that acidifies the body. Consequently, alkaline water has been used for improving bone density and healing.

Dissolved oxygen in water is essential for aquatic life. Deficiency of dissolved oxygen gives bad odour to water due to anaerobic decomposition of organic waste [12]. DO in the study ranges from 6.12 to $9.13 \mathrm{mg} / \mathrm{l}$ in location 1 and 6.0 to $7.2 \mathrm{mg} / \mathrm{l}$ in location 2 .

Phosphorus is the limiting nutrient in fresh water aquatic systems and it functions as the growthlimiting factor because it is usually present in very low concentrations. Excessive concentrations of phosphorus can quickly cause extensive growth of aquatic plants and algal bloom. Phosphorus concentration in excess of $0.015 \mathrm{mg} / \mathrm{L}$ and nitrogen concentration of about $0.3 \mathrm{mg} / \mathrm{L}$ are significant to cause algal bloom[13]. Phosphorus content in location $2 ; 0.166-0.17 \mathrm{mg} / \mathrm{l}$ is higher than location $1 ; 0.15-0.168 \mathrm{mg} / \mathrm{l}$

Sulphate has less effect on the taste of water compared to the presence of Chloride. However, at high concentrations, sulphate may induce dehydration, intestinal disorders and even diarrhoea. The sulphate levels of all the water samples were found to be higher than is permissible by NSDQW but lower than the $500 \mathrm{mg} / \mathrm{l}$ set by WHO.

Traces of Iron even at low concentrations are highly objectionable in water supplies for domestic use. It can cause staining of bathroom fixtures, can impart a brownish

Table1:Physico-Chemical Characteristics of Ihuku River from Culvert (Location 1) and Ukwunwangwu

$$
\text { (Location 2) }
$$

\begin{tabular}{|c|c|c|c|c|c|c|c|}
\hline $\begin{array}{c}\text { Test } \\
\text { parameters }\end{array}$ & $\begin{array}{c}\text { Upstream } \\
1\end{array}$ & $\begin{array}{c}\text { Upstream } \\
2\end{array}$ & $\begin{array}{l}\text { Mid- } \\
\text { stream } \\
1 \\
\end{array}$ & $\begin{array}{c}\text { Downstream } \\
1\end{array}$ & $\begin{array}{c}\text { Downstream } \\
2\end{array}$ & WHO & NSDQW \\
\hline $\begin{array}{l}\text { Temperature } \\
\left({ }^{0} \mathrm{C}\right)\end{array}$ & 27.5 & 27.0 & 24.3 & 27.0 & 26.5 & - & Ambient \\
\hline Colour & - & - & - & - & - & - & 15 (TCU) \\
\hline Odour & $\begin{array}{l}\text { Slightly } \\
\text { offensive }\end{array}$ & odourless & $\begin{array}{l}\text { Slightly } \\
\text { offensiv } \\
\text { e }\end{array}$ & $\begin{array}{l}\text { Slightly } \\
\text { offensive }\end{array}$ & Slightly offensive & - & $\begin{array}{l}\text { Unobjecti } \\
\text { onable }\end{array}$ \\
\hline $\begin{array}{l}\text { Total } \\
\text { Dissolved } \\
\text { Solids (mg/l) }\end{array}$ & 250 & 300 & 400 & 227 & 200 & - & 500 \\
\hline $\mathrm{pH}$ & 6.21 & 6.4 & 6.0 & 6.3 & 6.42 & - & $6.5-8.5$ \\
\hline $\begin{array}{l}\text { Hardness } \\
\left(\mathrm{CaCO}_{3} \mathrm{mg} / \mathrm{l}\right)\end{array}$ & 50 & 70 & 60 & 50 & 60 & - & 150 \\
\hline $\begin{array}{l}\text { Dissolved } \\
\text { Oxygen }\end{array}$ & 6.12 & 6.0 & 7.0 & 9.13 & 7.2 & - & - \\
\hline
\end{tabular}


An Assessment of the Physico-Chemical Parameters of Ihuku River

\begin{tabular}{|c|c|c|c|c|c|c|c|}
\hline $\begin{array}{l}\text { Biochemical } \\
\text { Oxygen } \\
\text { Demand }\end{array}$ & 2.0 & 2.1 & 1.5 & 1.42 & 1.52 & - & - \\
\hline \multicolumn{8}{|l|}{$\mathrm{ION}(\mathrm{mg} / \mathrm{l})$} \\
\hline $\mathrm{SO}_{4}^{2-}(\mathrm{mg} / \mathrm{l})$ & 268 & 250 & 285 & 266 & 284 & 500 & 100 \\
\hline $\mathrm{PO}_{4}{ }^{3-}(\mathrm{mg} / \mathrm{l})$ & 2.29 & 2.5 & 2.3 & 2.2 & 2.3 & - & - \\
\hline $\mathrm{Cl}^{-}$ & 213 & 245 & 284 & 222 & 260 & 250 & 250 \\
\hline \multicolumn{8}{|c|}{ Mineral (mg/l) } \\
\hline Calcium & 33.54 & 36.4 & 36.0 & 30.69 & 30.00 & - & - \\
\hline Magnesium & 0.09 & 0.05 & 0.10 & 0.051 & 0.08 & - & 0.20 \\
\hline Potassium & $81 * 10$ & $88 * 10$ & $92 * 10$ & $90 * 10$ & $80 * 10$ & - & - \\
\hline Sodium & $68 * 10$ & $67 * 10$ & $71 * 10$ & $69 * 10$ & $73 * 10$ & 200 & 200 \\
\hline Phosphorus & 0.164 & 0.17 & 0.168 & 0.15 & 0.166 & - & - \\
\hline \multicolumn{8}{|c|}{ Heavy Metals $(\mathrm{mg} / \mathrm{l})$} \\
\hline Lead & 0.015 & 0.05 & 0.013 & 0.015 & 0.05 & 0.01 & 0.01 \\
\hline Iron & 0.029 & 0.05 & 0.035 & 0.073 & 0.091 & - & 0.3 \\
\hline Zinc & 0.060 & 0.070 & 0.062 & 0.07 & 0.08 & 1.0 & 3.0 \\
\hline Copper & 0.041 & 0.70 & 0.062 & 0.69 & 0.88 & 2.0 & 1.0 \\
\hline Chromium & 0.058 & 0.071 & 0.044 & 0.068 & 0.07 & 0.05 & 0.05 \\
\hline Mercury & 0.002 & 0.004 & 0.003 & 0.003 & 0.004 & 0.006 & 0.001 \\
\hline Cadmium & 0.004 & 0.01 & 0.004 & 0.003 & 0.005 & 0.003 & 0.003 \\
\hline Nickel & 0.031 & 0.07 & 0.035 & 0.082 & 0.07 & 0.07 & 0.02 \\
\hline
\end{tabular}

WHO=World Health Organisation

NSDQW= Nigerian Standard for Drinking Water Quality

Upstream 1, Mid-stream 1and Downstream 1 are location points from culvert Ihuku referred to earlier as Location 1 while Upstream 2 and Downstream 2 are location points from Ukwunwangwu Ihuku referred to as Location 2

colour to laundered clothing and can affect the taste of water [8]. Iron in Location 1 is within range 0.029$0.073 \mathrm{mg} / \mathrm{l}$ and $0.05-0.091 \mathrm{mg} / \mathrm{l}$ for Location 2 . These although lower than permissible could be unfit for white fabrics.

Mercury is of global concern because of its persistence in the environment and its ability to accumulate in the body system for a long period of time. Its adverse effects include mental disturbance, impairment of speech, hearing, vision and movement [8]. This poses the mercury levels of this river as a potential threat even though its levels are slightly higher than permissible by NSDQW.

Nickel salts cause gastro intestinal irritation without inherent toxicity [8]. The Nickel contaminants in this study were found to be higher than is permissible especially at Downstream 2 in location 1 whose value is $0.082 \mathrm{mg} / \mathrm{l}$. Exposure to lead is associated with a wide range of effects, including various neurodevelopment effects, mortality (mainly due to cardiovascular diseases), impaired renal function, hypertension, impaired fertility and adverse pregnancy outcomes. At Location 2, the greatest lead value of $0.05 \mathrm{mg} / \mathrm{l}$ was found. This is greater than the $0.01 \mathrm{mg} / 1$ set by both WHO and NSDWQ.

The major sources of Cadmium and cadmium compounds are food, cigarette smoke and air pollution [8]. Its health effects can be either acute resulting from overexposure at high concentrations or chronic caused by the accumulation in the liver and renal cortex. Although classified a carcinogen through inhalation, there has been no evidence of its carcinogenicity by the oral route [8]; [7].

\section{Conclusion}

This study presented the levels of physicochemical parameters in water samples collected from Ihuku River. The results revealed that there was an indication of some physicochemical pollution in Ihuku although some values of these parameters are within acceptable range. Of greatest concern are the levels of some heavy metals such as Lead, Mercury, Chromium, Cadmium and Nickel whose levels were found to be slightly greater than set standards. The ability of these metals to persist in an environment and to accumulate in the body over years makes them a cause for worry. The study further revealed that although the water is unsafe for drinking, it cannot be termed completely unfit for other purposes because of its high DO and BOD values. This indicates a good buffering capacity.

Water pollution in this area should therefore be checked and its productivity enhanced. This is to guard against likely threat arising from future scarcity or reduced quality of their water resource and wetland following misuse. To achieve maximum outcome, this water pollution control should be supported by policy, adequate legal and institutional framework which are essential tools for sustainable development. The government should provide alternatives of better quality to this people. Education must play a central role in water management for instance the people should be taught to invest in rainwater harvesting for household consumption. It provides additional water supply and reduces pressures of demand on surrounding surface and groundwater resources. A number of skills and training initiatives, including electronic data management, water resource management 
training, technical training including water chemistry, biochemistry and microbiology, legal knowledge, and financial management need to be established [14]. Such capacity building will be a long-term process.

\section{References}

[1] J. C. Onweluzo and C. A.Akuagbazie, Assessment of the quality of bottled and sachet water sold in nsukka town,. Agro-Science Journal of Tropical Agriculture, Food, Environment and Extension 9 (2). 2010. 104 - 110

[2] E. Corcoran, C. Nellemann, E. Baker, R. Bos, D. Osborn,H. Savelli ,Sick water? The central role of wastewatermanagement in sustainable development. A rapid response assessment (Norway, BirkelandTrykkeri AS, 2010)

[3] C.S. James, Analytical chemistry of foods (New York, Chapman and Hall, 1965)

[4] American Public Health Association, Standard methods for the examination of waters and waste waters. (Washington D.C, APHA Press, 1998)

[5] R.Navone,Proposed method for nitrate in portable waters, Journal of American Water Works Association,56.1964.781

[6] G.Proft,Determination of total phosphorus in water and wastewater as molybdovanadophosphoric acid,Limnologica, 2.1964.407

[7] World Health Organization, Guidelines for drinking-water quality.( Geneva, WHO, 2011)

[8] J. M.Hammer and Jr.J.M. Hammer, Water and wastewater technology ( New Delhi, Prentice-Hall,2003)

[9] H.S.Mandal, A. Das and A. K. Nanda, Study of some physicochemical water quality parameters of karola river, west bengal - an attempt toestimate pollution status, $\quad$ International Journal of Environmental Protection,2(8).2012.16-22

[10] H.C. KAtaria, M.Gupta, M. Kumar, S.A. Kushwaha, S. Kashyap, S. Trivedi,, R. Bhadoriya and N. K. Bandewar ,Study of physicochemical parameters of drinking water of bhopal city with reference to health impacts,Current World Environment 6(1).2011.9599

[11] W.Kellas,A.Dworkin, Surviving the Toxic Crisis. Comprehensive Health, 1.1996. 523.

[12] N. Manivasakam,Physico-chemical examination of water, sewage and industrial effluents. (India,PragatiPrakashan, Meerut,1980).

[13] P.A.Oluwande, M.K.C. Sridhar, A.O. Bammeke and A. O Okubadejo, Pollution levels in some nigerian rivers, Water Res, 17.1993.957-963.

[14] E. H. Haigh,, H. E.Fox and H. D.Davies-Coleman, Framework for local government to implement integrated water resource management linked to water service delivery, Water SA 36.2010.1-12. 